\title{
Assessment of Physicochemical Parameters and Storage Stability of Reused Oils
}

\author{
Mohanavidhya* and P. Shamalabanu \\ Department of Foods and Nutrition, Vellalar College for Women, Erode, \\ Tamil Nadu, India; Suprithahari2009@gmail.com
}

\begin{abstract}
Oils are obtained from nuts and seeds of plants such as corn, groundnut, soyabean, olive, sunflower, cotton seed, palm, coconut and rape seed. Oils are extracted from the nuts or seeds by crushing and by the use of solvent extraction [1]. Deep fat frying is a popular food preparation method, where thermal stressing of polyunsaturated fatty acid, generates high levels of cytotoxic aldehydic products, arising from the fragmentation of conjugated hydroperoxydiene precursors. Such aldehydic compounds are damaging to human health [2]. Cooking oil is chemically decomposed in the cooking process and this decomposition leads to a deterioration in cooking quality, if the oil is kept in use for a long time [3]. Hence the present study was undertaken to assess the physicochemical parameters and storage stability of reused groundnut and palm oils. Results showed that physiochemical characteristics of oil were altered during repeated frying and storage and the changes in sensory attributes were also observed.
\end{abstract}

Keywords: Free Fatty Acid, Iodine Value, Physiochemical Characteristics, Saponification Number, Specific Gravity

\section{Introduction}

Groundnut and palm are important oilseed crops cultivated in India and a major portion of it is utilized for deep or shallow frying of foods either in the form of raw oil or after refining and hydrogenation. It is also used as edible oil for preparation of number of recipes by the largest segment of population. During frying vegetable oil is subjected to a temperature ranging from $180-250^{\circ}$ $\mathrm{C}$ and question arise regarding the wholesomeness of oil repeatedly used for frying purpose and subsequent storage. The oils and fats during heating in presence of air are partially converted into volatile products, nonvolatile oxidized derivatives, dimeric and polymeric cyclic substances and thus the physicochemical properties of oil are altered. The nature and extent of these changes depend very much on the type of oil and the way it is used for frying [4]. Reused oil gives rise to formation of free radicals. Free radicals attach themselves to healthy cells and lead to diseases. On heating the oil is smoky and it may have accumulated HNE (4 hydroxyl 2 nonenal) which is a toxic substance. Deep fat frying produces desirable or undesirable flavor compounds and changes the flavor stability and quality of the oil by hydrolysis, oxidation and polymerization. Tocopherols, essential amino acids and fatty acids in foods are degraded during deep fat frying. The reactions in deep fat frying depend on factors such as replenishment of fresh oil, frying conditions, original quality of frying oil, food materials, type of fryer, antioxidants and oxygen concentration. High frying temperature, the number of frying, the contents of free fatty acids, polyvalent metals and unsaturated fatty acids of oil decrease the oxidative stability and flavor quality of oil [5]. Hence the present study was undertaken with the objectives to assess physico chemical parameters of groundnut oil before and after frying and the storage stability of same reused oil at $30^{\text {th }}$ and $60^{\text {th }}$ day of storage and to assess the physicochemical parameters such as odour, colour, specific gravity, iodine value, free fatty acid and saponification value before frying and after $1^{\text {st }}$ 
and $2^{\text {nd }}$ frying to examine the wholesomeness of palm oil collected from street food vendors .

\section{Materials and Methods}

\subsection{Collection and Storage of Samples}

Unprocessed and processed oil samples were collected from the street food vendors ( 3 samples) and housewives (3 samples) each constituting about $200 \mathrm{ml}$.

The practice of many street food vendors is using the same deep fat fried oil repeatedly for two or three consecutive days. So, in order to assess the safety of oil, 3 samples of the Ruchi gold refined palmolien oil used for deep fat frying was collected from the street food vendors on the first day before and after deep fat frying and the same reused oil was collected on the second day and used for analysis.

In most households, the oil used for deep fat frying is filtered, stored and it is reused for seasoning, deep fat frying and shallow fat frying, etc. So three samples of the Manthara refined groundnut oil used for deep fat frying was collected from the housewives before and after deep fat frying and used for analysis.

People have been reusing oil for centuries without any acute poisoning but there is a concern over the long term effects. Most of the house wives cook the food by deep fry method and then they reuse the same oil by filtering it [6].

In order to do the analysis on storage stability of oil, the collected deep fat fried groundnut oil was stored for about 60 days in a stain less steel container individually at room temperature and they were subjected to analysis at 30 days interval.

Fats and oil undergo certain undesirable changes during storage which result in spoilage. The major kind of spoilage is known as rancidity. So, proper storage is essential [7].

\subsection{Assessing Physicochemical Characteristics and Storage Stability of Reused oil}

To detect the changes in physicochemical characteristics of oils, physical and chemical parameters were assessed. The physical properties such as colour, odour and specific gravity were determined in the collected oil samples. The chemical properties such as Iodine value, Free fatty acid value, saponification number and peroxide value were determined using standard procedure in the laboratory.

\subsection{Organloleptic Evaluation of Fried Foods}

Bajji was prepared using the stored oil (deep fat fried) at $30^{\text {th }}$ and $60^{\text {th }}$ day of storage and it was subjected to organoleptic evaluation.

Organoleptic evaluation is the composite characteristic, which determines the degree of acceptability of a specific product by the consumer. The quality attribute of the convenience food is broken into component characteristic like appearance, texture, flavour, taste and colour[8]. In organoleptic evaluation, 5 point numerical scoring was used to measure the consumer acceptability of food products using 15 semi trained panel members.

\subsection{Analysis of Data}

Data obtained through the above methods were consolidated and analyzed using mean, standard deviation and t- test.

\section{Results and Discussion}

\subsection{Physicochemical Characteristics of Groundnut Oil}

Details on physicochemical characteristics of groundnut oil before and after $1^{\text {st }}$ deep fat frying and frying after $30^{\text {th }}$ and $60^{\text {th }}$ day of storage at room temperature are represented in Figure 1.

A steady increase in acid value, saponification number, peroxide value, specific gravity value and decrease in iodine value was noted in oil subjected to frying during storage, it might be due to degradation products of oil during heating at a high temperature for long time.

The free fatty acid content increases during heating. Moisture present in the food material fried tends to hydrolyze the fat and increase the free fatty acid content [9]. Peroxide value is used to measure the lipid oxidation in the oil. The peroxides formed are unstable and yield volatile aldehydes, ketones, alcohols and acids [10].

\subsection{Comparison of Mean Overall Acceptability Scores of Bajji}

Mean overall acceptability scores of bajji prepared in fresh oil and stored reused groundnut oil (30 day and 60 days) are presented in Table 1. 


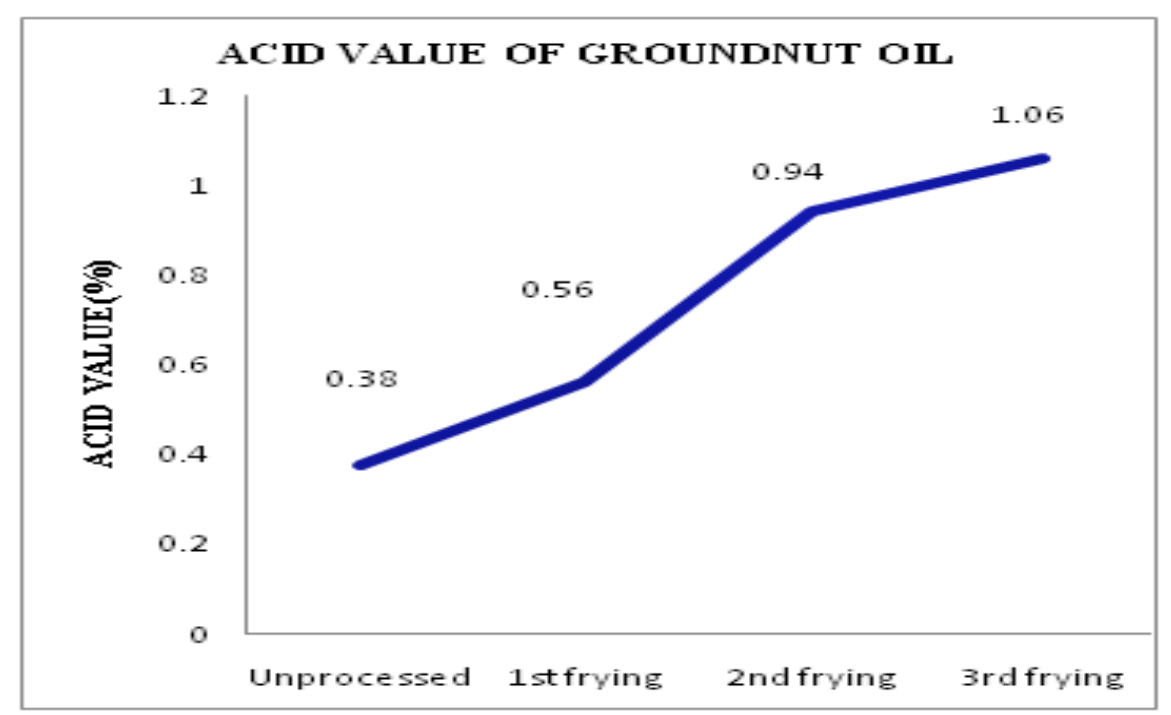

(a)

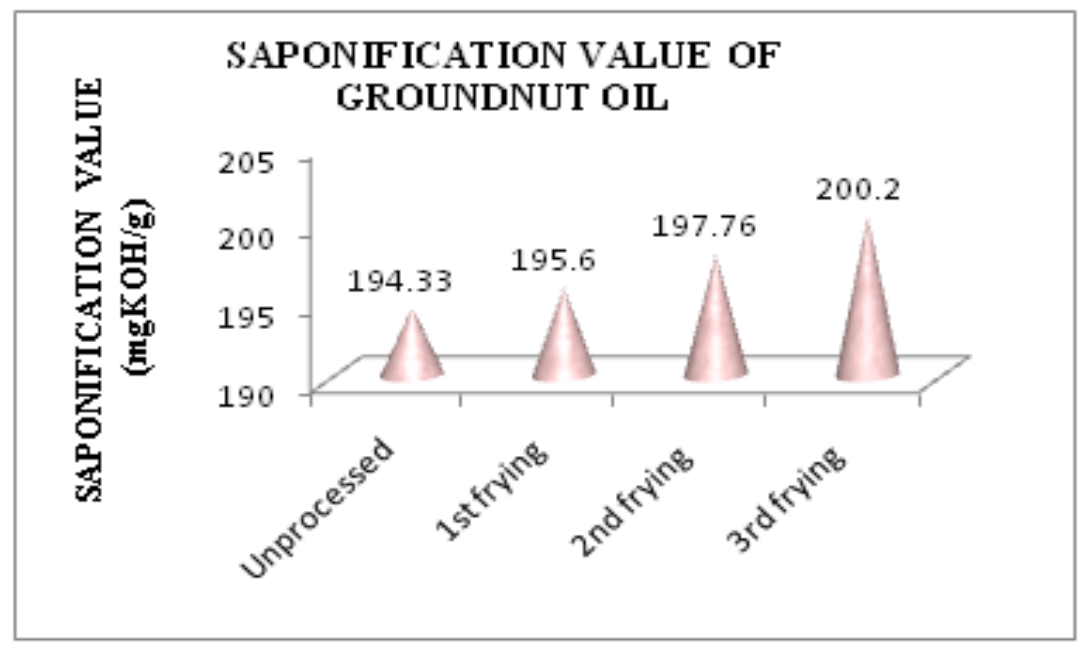

(b)

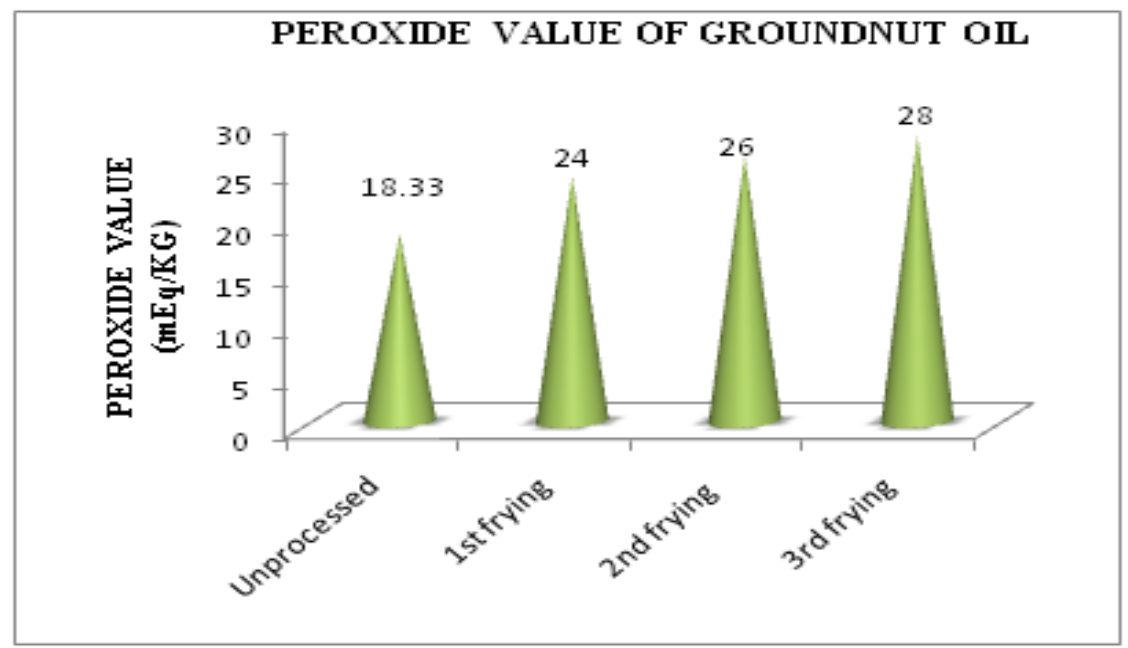

(c) 


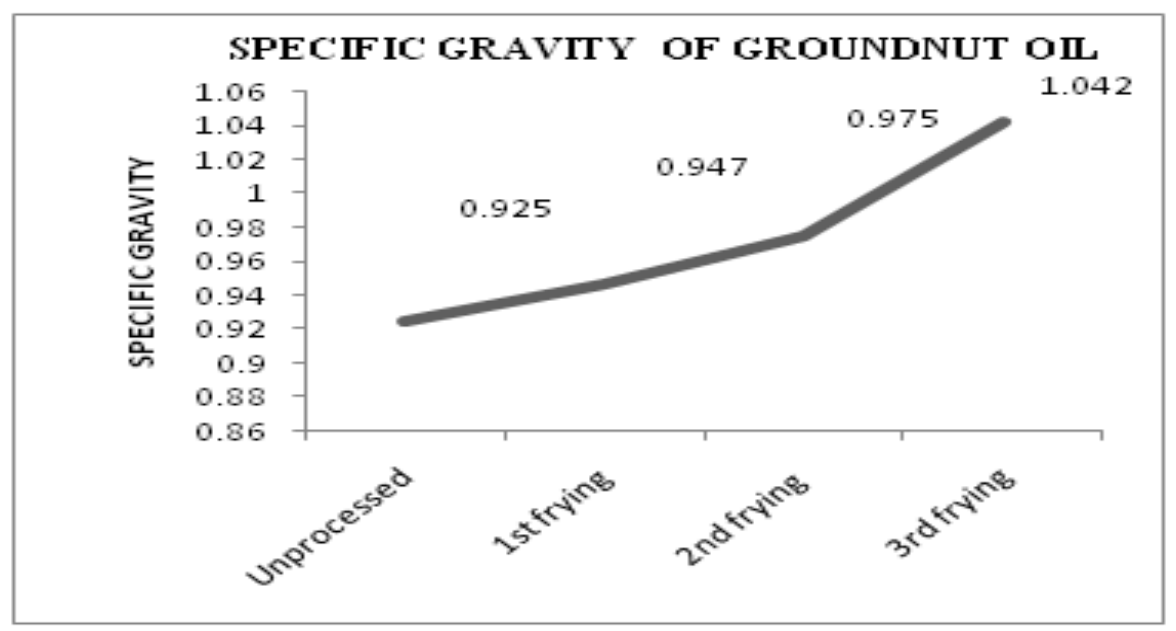

(d)

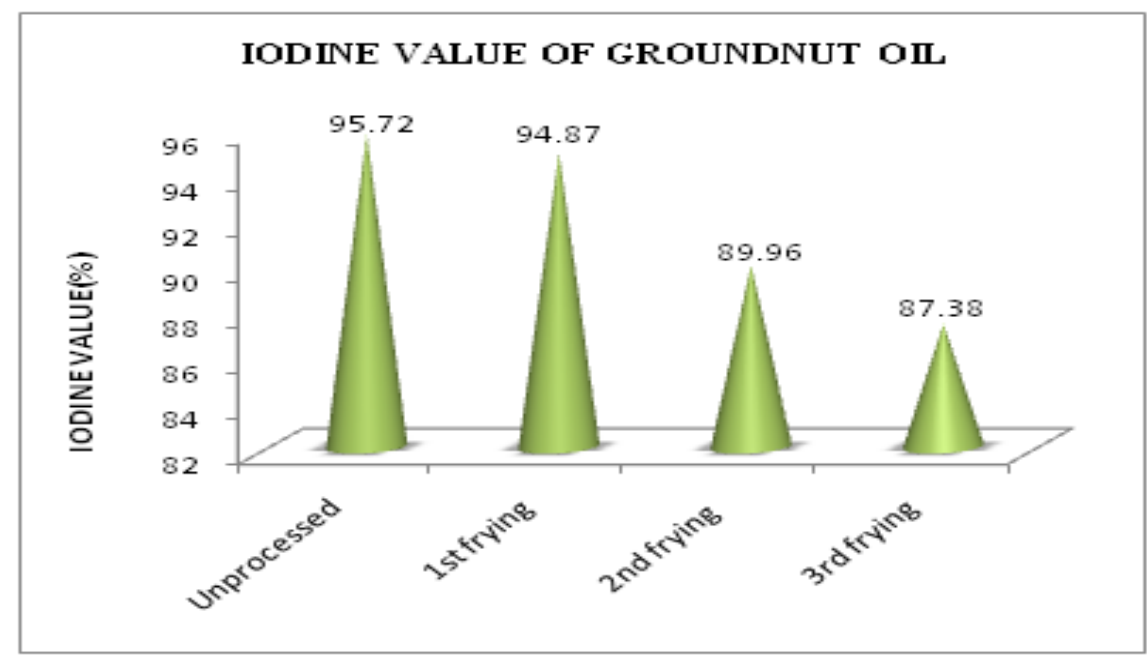

(e)

Figure 1. Physicochemical characteristics of groundnut oil before and after deep fat frying.

Table 1. Mean overall acceptability scores of bajji prepared in fresh oil and reused groundnut oil

\begin{tabular}{|l|c|c|c|c|c|c|c|}
\hline \multirow{2}{*}{ Criteria } & \multicolumn{4}{|c|}{ Mean \pm Standard deviation (30 day) } & \multicolumn{3}{c|}{ Mean \pm Standard deviation(60 day) } \\
\cline { 2 - 8 } & Std & Sample I & Sample II & SampleIII & Sample I & SampleII & Sample III \\
\hline Appearance & 5 & $4.80 \pm 0.41$ & $4.78 \pm 0.45$ & $4.73 \pm 0.45$ & $4.53 \pm 0.51$ & $4.33 \pm 0.48$ & $4.4 \pm 0.50$ \\
\hline Flavour & 5 & $4.46 \pm 0.51$ & $4.33 \pm 0.72$ & $4.53 \pm 0.51$ & $4.26 \pm 0.45$ & $4.33 \pm 0.48$ & $4.0 \pm 0.37$ \\
\hline Taste & 5 & $4.20 \pm 0.56$ & $4.4 \pm 0.50$ & $4.33 \pm 0.72$ & $4.26 \pm 0.59$ & $3.73 \pm 0.45$ & $3.66 \pm 0.61$ \\
\hline Texture & 5 & $3.60 \pm 0.61$ & $3.73 \pm 0.70$ & $3.60 \pm 0.63$ & $3.86 \pm 0.35$ & $3.66 \pm 0.48$ & $3.53 \pm 0.51$ \\
\hline $\begin{array}{l}\text { Overall } \\
\text { acceptability }\end{array}$ & 5 & $4.26 \pm 0.52$ & $4.29 \pm 0.59$ & $4.29 \pm 0.58$ & $4.22 \pm 0.47$ & $4.01 \pm 0.47$ & $3.92 \pm 0.53$ \\
\hline $\begin{array}{l}\text { Group compared } \\
\text { T' test }\end{array}$ & - & $\begin{array}{c}\text { Standard and } \\
\text { Sample I }\end{array}$ & $\begin{array}{c}\text { Standard and } \\
\text { Sample II }\end{array}$ & $\begin{array}{c}\text { Standard and } \\
\text { Sample III }\end{array}$ & $\begin{array}{c}\text { Standard and } \\
\text { Sample I }\end{array}$ & $\begin{array}{c}\text { Standard and } \\
\text { Sample II }\end{array}$ & $\begin{array}{c}\text { Standard and } \\
\text { Sample III }\end{array}$ \\
\hline $\begin{array}{l}\text { Level of } \\
\text { Significance }\end{array}$ & - & 2.620 & 4.872 & 4.873 & 3.464 & 5.758 & 7.940 \\
\hline
\end{tabular}


From the Table 1 it was revealed that standard bajji prepared using the fresh oil, got maximum scores for all the parameters. The mean overall acceptability score was around 4.2 for all three samples tested on stored reused oil on $30^{\text {th }}$ day. Statistical analysis revealed that there was a significant difference between $\mathrm{t}$ standard and all the three samples.

Table 1 indicates that the mean overall acceptability scores for bajji prepared using 60 days stored reused ground nut oil was very low for all the three samples. The lowest score was obtained for texture. The bajji was soggy, this shows that the oil absorption capacity got increased, when stored reused oil was used for frying. Statistical analysis revealed that there was a significant difference between standard and all the three samples.

\subsection{Sensory Evaluation of Stored and Reused Groundnut Oil}

The data on sensory evaluation of colour and odour of reused groundnut oil at $30^{\text {th }}$ and $60^{\text {th }}$ day of storage is represented in Table 2.

From the table it was revealed that the mean score for colour of groundnut oil during storage increased from 1.433 to 1.7 at the end of $60^{\text {th }}$ day of storage. The increase in colour, could be probably because of browning of oil during repeated frying. Regarding odour, after deep fat frying at the end of 30 days of storage, the score for odour was $1.73 \pm 0.534$ and it deviates to about 2.06 after deep fat frying at $60^{\text {th }}$ day of storage. Cooked flavour in the deep fat fried oil after $60^{\text {th }}$ day of storage was noticed.

\subsection{Physicochemical Characteristics of Palm Oil}

Details on physicochemical characteristics of unprocessed palm oil, after $1^{\text {st }}$ deep fat frying and $2^{\text {nd }}$ deep fat frying are represented in Table 3.

\subsection{Sensory Evaluation of Palm Oil}

The data on colour and odour of palm oil after $1^{\text {st }}$ and $2^{\text {nd }}$ deep fat frying are presented in Table 4 .

Table 4 indicates that there was an increase in scores for colour and odour of palm oil after $1^{\text {st }}$ and $2^{\text {nd }}$ deep fat frying. Consistency was highly viscous, food colour was predominant and fishy odour was higher after $2^{\text {nd }}$ frying. Large difference in colour and flavor of palm oil might be due to high temperature used for frying, prolonged heating and the addition of food colours by the street food vendors.

The ingredients in the product being fried influence the colour changes of the frying fat. Potatoes form little

Table 2. Mean scores for colour and odour of reused groundnut oil

\begin{tabular}{|l|c|c|c|c|}
\hline \multirow{2}{*}{$\begin{array}{l}\text { Groundnut } \\
\text { oil }\end{array}$} & \multicolumn{2}{|c|}{ Colour } & \multicolumn{2}{c|}{ Odour } \\
\cline { 2 - 5 } & $\mathbf{3 0}$ days & $\mathbf{6 0}$ days & $\mathbf{3 0}$ days & $\mathbf{6 0}$ days \\
\hline Sample I & $1.4 \pm 0.516$ & $1.6 \pm 0.316$ & $1.4 \pm 0.516$ & $1.8 \pm 0.421$ \\
\hline Sample II & $1.5 \pm 0.527$ & $1.7 \pm 0.527$ & $1.8 \pm 0.421$ & $2.2 \pm 0.632$ \\
\hline Sample III & $1.4 \pm 0.516$ & $1.8 \pm 0.527$ & $2.0 \pm 0.666$ & $2.2 \pm 0.632$ \\
\hline Mean & $1.43 \pm 0.519$ & $1.7 \pm 0.454$ & $1.73 \pm 0.534$ & $2.06 \pm 0.561$ \\
\hline
\end{tabular}

Table 3. Physicochemical characteristics of palm oil

\begin{tabular}{|l|c|c|c|}
\hline \multirow{2}{*}{$\begin{array}{l}\text { Physico Chemical } \\
\text { Parameters }\end{array}$} & \multicolumn{3}{|c|}{ Mean \pm Standard Deviation Values } \\
\cline { 2 - 4 } & Unprocessed & $\mathbf{1}^{\text {st }}$ frying & $2^{\text {nd }}$ frying \\
\hline Acid value & 1.75 & $3.75 \pm 0.05$ & $6.34 \pm 0.17$ \\
\hline Saponification Value & 198 & $202.3 \pm 2.51$ & $252.33 \pm 2.5$ \\
\hline Peroxide Value & 3.20 & $4.76 \pm 0.07$ & $6.40 \pm 0.315$ \\
\hline Specific Gravity & 0.92 & $0.975 \pm 0.006$ & $1.093 \pm 0.005$ \\
\hline Iodine Value & 56.81 & $53.86 \pm 0$ & $52.95 \pm 0.76$ \\
\hline
\end{tabular}


Table 4. Mean scores for colour and odour of palmoil

\begin{tabular}{|l|c|c|c|c|}
\hline \multirow{2}{*}{ Criteria } & \multicolumn{2}{|c|}{ Colour } & \multicolumn{2}{c|}{ Odour } \\
\cline { 2 - 5 } & $\mathbf{1}^{\text {st }}$ day frying & $2^{\text {nd }}$ day frying & $1^{\text {st }}$ day frying & $2^{\text {nd }}$ day frying \\
\hline Sample I & $1.3 \pm 0.483$ & $2.9 \pm 0.316$ & $1.6 \pm 0.516$ & $2.4 \pm 0.516$ \\
\hline Sample II & $1.4 \pm 0.516$ & $2.5 \pm 0.527$ & $1.6 \pm 0.516$ & $2.4 \pm 0.516$ \\
\hline Sample III & $1.5 \pm 0.527$ & $2.5 \pm 0.527$ & $1.4 \pm 0.516$ & $2.4 \pm 0.516$ \\
\hline Mean & $1.4 \pm 0.508$ & $2.6 \pm 0.454$ & $1.53 \pm 0.516$ & $2.4 \pm 0.516$ \\
\hline
\end{tabular}

Table 5. Physicochemical characteristics of groundnut and palm oils

\begin{tabular}{|l|c|c|}
\hline Parameters & Groundnut oil & Palm oil \\
\hline Acid value $(\%)$ & 180.32 & 262.47 \\
\hline Saponification value $(\mathrm{mgKOH} / \mathrm{g})$ & 2.98 & 27.43 \\
\hline Peroxide value $(\mathrm{mEq} / \mathrm{kg})$ & 52.82 & 100.20 \\
\hline Specific gravity & 13.21 & 18.83 \\
\hline Iodine value $(\%)$ & -8.70 & -6.78 \\
\hline
\end{tabular}

colour in the frying fat, whereas chicken and egg yolk increases darkening of the fat [11].

\subsection{Comparison on Physiochemical Characteristics of Groundnut and Palm Oil}

The physiochemical properties of stored, reused groundnut oil at $60^{\text {th }}$ day of storage and palm oil after $2^{\text {nd }}$ day of frying are given in Table 5 .

From the Table 5 it was evident that on comparing the stored reused groundnut oil and reused palm oil, the change in physicochemical characteristics was highly noticed in palm oil. It might be due to variation in temperature used for frying and prolonged heating of oil practiced by street food vendors.

\section{Conclusion}

Hence it may be concluded from the above finding that the repeated heating of oil lead to a changes in sensory and physicochemical characteristics. Our investigation observed large difference in the physicochemical characteristics between $1^{\text {st }}, 2^{\text {nd }}$ and $3^{\text {rd }}$ time of deep fat frying of groundnut oil (i.e) during repeated heating. The maximum increase in acid value, saponification value, peroxide value, specific gravity value and decrease in iodine value could be because of degradation products formed in oil during heating at a high temperature for long time. Foods prepared from reused and stored groundnut oil was not highly acceptable and odour and colour of palm oil became unacceptable even at the end of $2^{\text {nd }}$ day of deep fat frying. While comparing the frying quality of groundnut and palm oil, a physicochemical changes was highly noticed in palm oil. This shows the harmful effects of street food. So it is advisable to use fresh oil for deep fat frying, shorten the period of storage of reused oil and consumption of street foods should also be restricted.

\section{References}

1. Gaman P. M., and Sherrington K. B. The science of food; British Library cataloguing in publication and library of congress cataloging in publication, 3rd Edition, 1994. p. 63-66.

2. Quiles J. L., Huertas J. R., Battino M., Ramirez T. M. C., Cassinello M., Mataix J., Lopez F. M., and Manas M. “The intake of fried virgin olive or sunflower oils differentially induces oxidative stress in rat liver microsomes", Br J Nutr. Jul, vol. 88(1), p. 57-65, 2002.

3. Srilakshmi B. Food science, 5th Edition, New age international publishers, 2013. p. 228-229.

4. Vidyasagar K., Arya S. S., Premavathi K. S., Parihar D. B., and Nath H. "Chemical and nutritive changes in refined groundnut oil during deep fat frying", Journal of Food Science and Technology, vol. 11, p. 73-75, 1994. 
5. Choe E., and Min D. B. "Chemistry of deep fat frying oils", Journal food science, vol. 72(5), p. 77-86, 2007.

6. Siazia T., Codony R., and Rafecas M. "Health effect of groundnut oil”, J Hum Ecol, vol. 26(3), p. 197-203, 2012.

7. Mudambi R., and Rao M. Food science, New age international (P) limited, 1997. p. 141-142.

8. Peter S., and Murano. Understanding food science and technology, Thomson wadsworth Publisher, 2003. p. 364365.
9. Geetha S., and Mary G. Laboratory chemical methods in food analysis, Margham publications, 2002. p. 90-91.

10. Sathe A. A first course in food analysis, New age international (P) limited publishers, 1999. p. 82.

11. Pawar V. D., Machewad G. M., and Ghatge P. U. "Physicochemical characteristics and storage stability of groundnut oil after deep frying of low moisture food", Beverage and Food World, vol. 41(2), p. 51-52, 2014. 